\title{
DISCORDANT U-Pb ISOTOPIC SYSTEM IN ZIRCONS FROM A GRANITE NORTH-WEST OF FREDERIKSHÅBS ISBLINK, FISKENÆSSET REGION
}

\author{
R. T. Pidgeon
}

\begin{abstract}
Introduction
Extensive sampling was carried out in parts of the Fiskenæsset region during the 1971 field season with the aim of providing suitable material for isotopic age determinations. The total area covered by the mapping programme was so large and the geological problems so varied that it was decided to initiate this study by looking in detail at a small number of rock types in one or two sub-areas. Once isotopic relationships are known in these areas it is hoped to extend the work to embrace other problems in the region. The laboratory work is in progress at present and already some preliminary results have been obtained (Feb. 1972). It is the purpose of this report to discuss the age relationships of zircons extracted from a single $100 \mathrm{~kg}$ sample of granite from the mapping area of Hopgood (see plate 1).
\end{abstract}

\section{Geological relationships of the granite}

The sample (GGU 112526) is a massive, medium-grained, porphyroblastic, granitic rock which because of a very low potash feldspar content is more correctly termed a granodiorite, though the field term of 'granite' is retained in this report. Hopgood (this issue p. 23) considers this rock type to be a palingenetic development of the pre-existing gneisses.

Regarding the position of the granite in the geological history Hopgood states that "The latest folds recognised as having been affected by the palingenesis are those ascribed to the fourth fold generation in the gneiss". "... a faint steep to vertical lineation [in the granites] parallel to east-trending axial planes related to the fifth recognised generation of folding, indicates that palingenesis took place prior to this episode of folding". From this it is clear that the formation of this granite took place rather late in the geological history of the Fiskenæsset region and it must be with this in mind that we assess the significance of the geochronological results. 


\section{Zircon population}

It is not proposed to describe the zircons in any detail in this preliminary report. It is noted however that the zircon population from GGU 112526 was homogeneous and consisted of light brown crystals grading from those with clear cut to those with blunted terminations. Inclusions were rare though rounded central zircon cores were common. Necked crystals were frequently observed and twinned zircons were common. It may be concluded from these observations that the zircon population has experienced a complex growth history.

\section{U-Pb isotopic analyses and the age of the granite zircons}

The results of uranium and lead isotopic analyses of four size splits of the nonmagnetic portion of the zircon population are shown in table 4. Important points to note from the table are firstly the $\mathrm{Pb}{ }^{206} / \mathrm{Pb}^{204}$ ratios. This ratio gives an indication of the common lead contamination. In the present case all ratios exceed 4500 indicating that any small uncertainty in the common lead correction applied to the data will have no significant effect on the age results. A second point to note is the discordant pattern in the apparent age columns. Clearly the zircon U-Pb systems have been disturbed since formation of the zircons. The most realistic age with respect to the age of the zircons is the $\mathrm{Pb}^{207 /} \mathrm{Pb}^{206}$ age which gives a lower limit to the age of crystallisation. This apparent age itself varies from $2790 \mathrm{~m}$. y. in the coarsest to $2870 \mathrm{~m}$. y. in the finest fraction.

In order to investigate further the discordant behaviour of the zircons the $\mathrm{Pb} / \mathrm{U}$ isotopic ratios have been plotted on a concordia plot (fig. 4). It can be seen from the figure that the data points are linearly related on a chord which

Table 4. U-Pb isotopic analyses of zircon fractions from a granite (GGU 112526) north-west of Frederikshåbs Isblink

\begin{tabular}{|c|c|c|c|c|c|c|c|c|c|c|c|c|}
\hline \multirow{3}{*}{$\begin{array}{l}\text { Zircon } \\
\text { Fraction }\end{array}$} & \multirow{3}{*}{$\begin{array}{c}\mathrm{Pb} \\
\mu \mathrm{g} / \mathrm{g}\end{array}$} & \multirow{3}{*}{$\begin{array}{c}\mathrm{U} \\
\mu \mathrm{g} / \mathrm{g}\end{array}$} & \multirow{3}{*}{$\frac{\mathrm{Pb}^{206}}{\mathrm{~Pb}^{204}}$} & \multicolumn{3}{|c|}{$\begin{array}{c}\text { Radiogenic lead } \\
\text { in atom. per cent }\end{array}$} & \multicolumn{3}{|c|}{ Atomic Ratios } & \multicolumn{3}{|c|}{$\begin{array}{l}\text { Apparent Ages* } \\
\text { in m.y. }\end{array}$} \\
\hline & & & & 206 & 270 & 200 & $\mathrm{~Pb}^{207}$ & $\mathrm{~Pb}^{207}$ & $\mathrm{~Pb}^{206}$ & $\mathrm{~Pb}^{207}$ & $\mathrm{~Pb}^{207}$ & $\mathrm{~Pb}^{206}$ \\
\hline & & & & 200 & 270 & 208 & $\overline{\mathrm{Pb}^{206}}$ & $\overline{U^{235}}$ & $\overline{U^{23} .}$ & $\mid \overline{\mathbf{P b}^{206}}$ & $\overline{\mathbf{U}^{235}}$ & $\overline{\mathrm{U}^{23}}$. \\
\hline$+142 \mu$ & 293.0 & 527.3 & 6000 & 82.00 & 15.59 & 2.403 & 0.1904 & 11.68 & 0.4453 & 2790 & 2612 & 2397 \\
\hline$-142+106 \mu$ & 230.4 & 461.3 & 6390 & 80.95 & 15.91 & 3.139 & 0.1966 & 12.74 & 0.4701 & 2840 & 2695 & 2508 \\
\hline$+84+62 \mu$ & 217.3 & 417.4 & 6250 & 80.12 & 15.98 & 3.90 & 0.1995 & 13.34 & 0.4849 & 2868 & 2740 & 2570 \\
\hline$-30 \mu$ & 229.0 & 436.5 & 4825 & 79.58 & 15.93 & 4.49 & 0.2002 & 13.40 & 0.4853 & 2870 & 2744 & 2575 \\
\hline
\end{tabular}

* Calculated with the following constants $U^{235} / U^{23} .=1 / 137.8, \lambda U^{23} .=1.53 \times 10^{-10} y^{-1}$, $\lambda \mathrm{U}^{235}=9.72 \times 10^{-10} \mathrm{y}^{-1}$, 


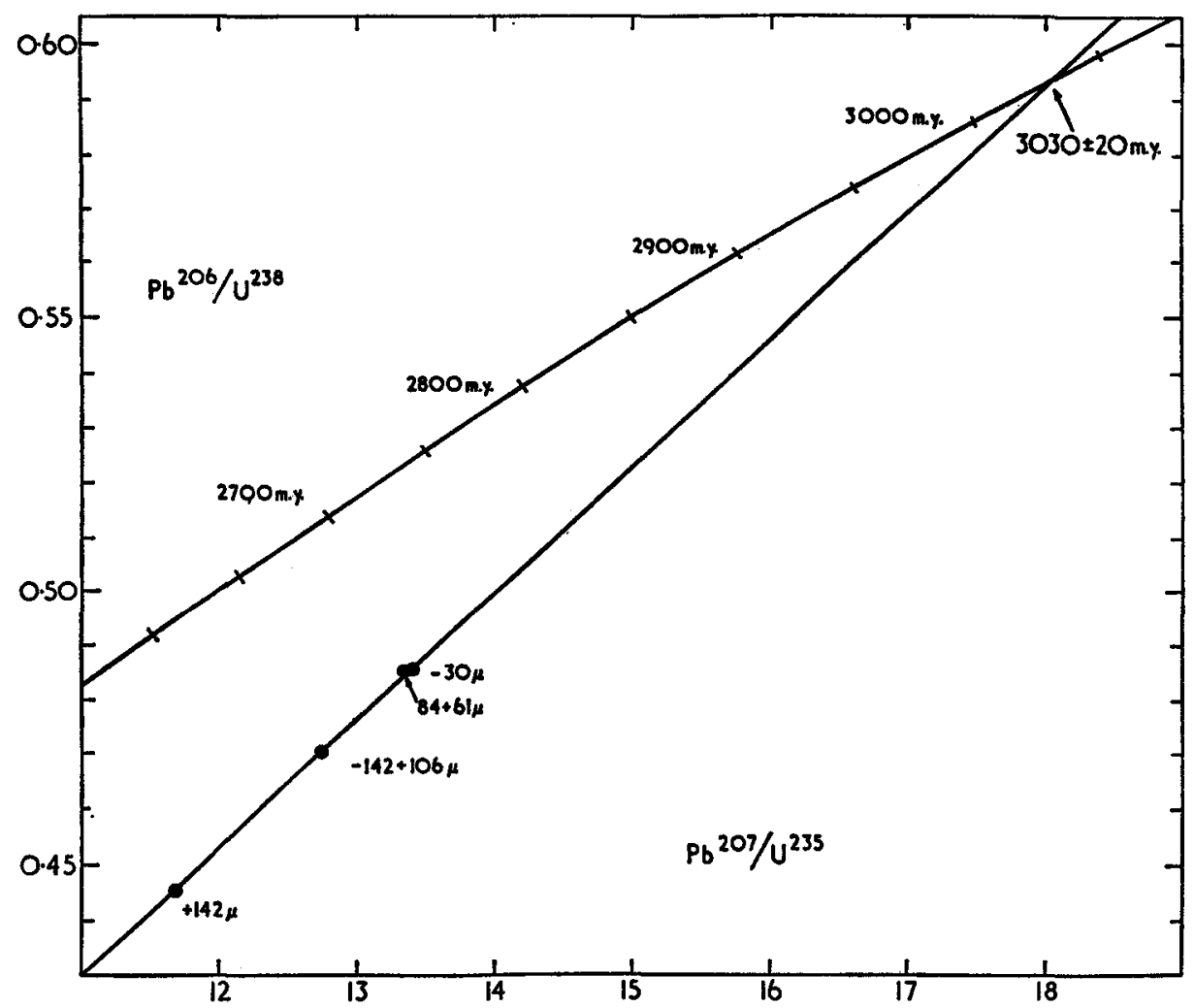

Fig. 4 Section of a concordia plot showing the intersection of the chord through the datapoints of the granite zircons and the concordia at $3030 \pm 20 \mathrm{~m} . \mathrm{y}$.

intersects the concordia curve at $3030 \pm 20 \mathrm{~m}$. y. Assuming an 'episodic disturbance model' or a model of 'lead loss by slow continuous diffusion' this age can be interpreted as the age of initial formation of zircon.

Additional work, both $\mathrm{Rb}-\mathrm{Sr}$ and $\mathrm{U}-\mathrm{Pb}$, is at present in progress to test this explanation. Assuming further work confirms that the age of zircon crystallisation in the granites took place approximately $3030 \mathrm{~m}$. y. ago, then by implication, a considerable portion of the geological history in the Fiskenæsset region took place before this. 